\title{
Article
}

http://dx.doi.org/10.11646/phytotaxa.177.5.1

\section{Phylogenetic position of the diatom genus Geissleria Lange-Bertalot \& Metzeltin and description of two new species from Siberian mountain lakes}

\author{
MAXIM KULIKOVSKIY ${ }^{1 *}$, EVGENIY GUSEV ${ }^{1}$, SVETLANA ANDREEVA ${ }^{2} \&$ NATALIA ANNENKOVA ${ }^{3,4}$ \\ ${ }^{I}$ Department of Water Plants taxonomy and Geography, I.D. Papanin Institute for Biology of Inland Waters, Russian Academy of \\ Sciences, 152742 Yaroslavl, Nekouz, Borok; Russia \\ ${ }^{2}$ S.- Petersburg State University, Universitetskaya nab., 7-9, St. Petersburg, 199034, Russia \\ ${ }^{3}$ Limnological Institute Siberian Division, Russian Academy of Sciences, Ulan-Batorskaya 3, RUS-664033, Irkutsk, Russia \\ ${ }^{4}$ Aquatic Ecology, Department of Biology, Lund University, Ecology Building, 22362 Lund, Sweden \\ *Corresponding author, e-mail:_max-kulikovsky@yandex.ru
}

\begin{abstract}
Two new Geissleria species from Siberian mountain lakes Baikal and Frolikha are described based on molecular and morphological data. The two new species are Geissleria baicalosimilis Kulikovskiy, Gusev, Andreeva \& Annenkova sp. nov. and G. frolikhiensis Kulikovskiy, Gusev, Andreeva \& Annenkova sp. nov. According to partial 18S rDNA and $r b c \mathrm{~L}$ gene fragment analyses, Geissleria does not belong to the large catch-all genus Navicula as it was previously thought. Morphological features such as slit like areolae without hymenes, presence of one isolated pore near the central nodule and presence of props in areolae and an annulus structure support this conclusion. Plastid morphology of Geissleria species is typical for the Cymbellales, with one large chloroplast divided into two plates lying one against each valve, connected by a broad column. All of our data show that Geissleria is most closely to the genus Placoneis, with which they share naviculoid symmetry. Given these results, Geissleria should be included in the order Cymbellales.
\end{abstract}

Key words: Cymbellales diatoms, Geissleria, morphology, phylogenetic position, new species, lakes, Baikal, Frolikha

\section{Introduction}

The genus Geissleria was described by Lange-Bertalot and Metzeltin (1996: 66) typified with Geissleria moseri Metzeltin, Witkowski \& Lange-Bertalot (1996: 66-67) (Lange-Bertalot \& Metzeltin 1996). Their new genus included taxa from the section Annulatae Hustedt of the genus Navicula Bory (1822: 128) sensu lato. According to LangeBertalot and Metzeltin (1996) and Lange-Bertalot (2001) this genus is characterized by solitary cells and biraphid, isovalvar, isopolar frustules. The internal raphe-sternum system is without the complication of super-imposed raphe costa like in the genus Navicula sensu stricto. Most species possess a simple stigma close to the central nodule. The most unique feature of the genus Geissleria is the presence of groups of peculiar subpolar areolae, elongated apically (annulus); the apical frets between these areolae possess numerous warty outgrowths (Lange-Bertalot \& Metzeltin 1996, Lange-Bertalot 2001). Lange-Bertalot (2001) considers the systematic position of this genus to be within the naviculoid diatoms. According to Novais et al. (2013), the lack of internal hymens, present in Navicula s.s. and the presence of additional small props between the pores are reminiscent of cymbelloid diatoms. According to Novais et al. (2013) species of the genus Geissleria have an isolated pore (stigma sensu Lange-Bertalot 2001). Novais et al. (2013) have postulated that the exact taxonomic position of Geissleria species should be clarified using molecular techniques. The genus Geissleria currently comprises 74 taxa, distributed worldwide in different freshwater reservoirs such as lakes, rivers, springs, waterfalls and can occur epilithically, epiphytically or in soils (Novais et al. 2013). Revision of species with comprehensive references is given in Novais et al. (2013).

Modern determinations of the phylogenetic relationships of organisms are usually based on both morphological observations and DNA analysis. Molecular genetic studies of diatom taxa have already been carried out at higher taxonomic categories, at the level of genus and for describing new species (see Behnke et al. 2004, Medlin \& 
like areolae (Figs 44-49). The props are present around the edges of the annulus areolae in Geissleria (Figs 44-47). The same props surround the isolated areolae at the valve poles in Geissleria (Fig. 44, 45). These dolioform props are similar with props are visible around the edges of the areolae in incomplete pores of Placoneis (Fig. 50). In Placoneis these props are covered by round or squatrish flap-like coverings. The pore occlusions are each termed a tectulum ("little roof") according to Cox (2004). Props can be distinguished in pores of pore fields in the genus Cymbella (Fig. 51). These data support the opinion of Mann $(1981)$ and Cox $(2004,2012)$ that similar pore occlusions should characterize natural, monophyletic groups.

Discovery of two new species of Geissleria from Lake Baikal and Lake Frolikha, supports our idea that Transbaikal lakes are hotspots for many endemic species (Kulikovskiy et al. 2012a, Gusev \& Kulikovskiy 2013, Kulikovskiy \& Kociolek 2014). Future investigations of diatom diversity from water bodies of this area using additional molecular techniques are important for clarifying phylogenetic position of some genera, not yet studied, and for revealing species diversity and biogeography of freshwater species.

\section{Acknowledgements}

The publication is based on research carried out with financial support provided the Russian President Foundation (MK-1128.2012.4) and RFBR (14-04-01406-a). Some parts of this work were prepared with help of Resource Center for molecular and cell technologies of Saint-Petersburg State University. The authors appreciate very much the help of Professor Pat Kociolek in correcting the English and important discussion.

\section{References}

Abarca, N., Jahn, R., Zimmermann, J., Enke, N. (2014) Does the cosmopolitan diatom Gomphonema parvulum (Kützing) Kützing have a biogeography? PLoS ONE 9(1): 1-18. http://dx.doi.org/10.1371/journal.pone.0086885

Agardh, C.A. (1830) Conspectus Criticus Diatomacearum. Part 1: 1-16. Lundae. Litteris Berlingianis.

Alverson, A.J. \& Theriot E.C. (2005) Comments on recent progress toward reconstructing the diatom phylogeny. J. Nanosci. Nanotechnol. 5: $57-62$.

http://dx.doi.org/10.1166/jnn.2005.007

Alverson, A.J., Cannone, J.J., Gutell, R.R. \& Theriot E.C. (2006) The evolution of elongate shape in diatoms. Journal of Phycology 42: $655-668$. http://dx.doi.org/10.1111/j.1529-8817.2006.00228.x

Benhke, A., Friedl, T., Chepurnov, V.A. \& Mann, D.G. (2004) Reproductive compatibility and rDNA sequence analysis in the Sellaphora pupula species complex (Bacillariophyta). Journal of Phycology 40(1): 193-208. http://dx.doi.org/10.1046/j.1529-8817.2004.03037.x

Bory de Saint-Vincent J-B.G.M. (1822) Dictionnaire Classique d'Histoire Naturelle. Vol. 2. Paris. http://dx.doi.org/10.5962/bhl.title.33901

Bruder, K. \& Medlin, L.K. (2007) Molecular assessment of phylogenetic relationships in selected species/genera in the naviculoid diatoms (Bacillariophyta). I. The genus Placoneis. Nova Hedwigia 85(3-4): 331-352. http://dx.doi.org/10.1127/0029-5035/2007/0085-0331

Bruder, K. \& Medlin, L.K. (2008a) Morphological and molecular investigations of naviculoid diatoms. II. Selected genera and families. Diatom Research 23(2): 283-329. http://dx.doi.org/10.1080/0269249x.2008.9705759

Bruder, K. \& Medlin, L.K. (2008b) Morphological and molecular investigations of naviculoid diatoms. III. Hippodonta and Navicula s.s. Diatom Research 23(2): 331-347. http://dx.doi.org/10.1080/0269249x.2008.9705760

Bruder, K., Sato, S. \& Medlin L.K. (2008) Morphological and molecular investigations of naviculoid diatoms IV. Pinnularia vs. Caloneis. Diatom 24: 8-24.

Cleve, P.T. \& Grunow, A. (1880) Beiträge zur Kenntniss der Arctischen Diatomeen. Kongliga Svenska-Vetenskaps Akademiens Handlingar 17(2): 1-121.

Cleve, P.T. \& Möller, J.D. (1882) Diatoms. Part VI, Esatas Edquists Boktryckeri, Upsala, 48 pp. [pp. 277-324]

Cox, E.J. (1987) Placoneis Mereschkowsky: the re-evaluation of a diatom genus originally characterized by its chloroplast type. Diatom 
Research 2: 145-157.

http://dx.doi.org/10.1080/0269249x.1987.9704994

Cox, E.J. (2004) Pore occlusion in raphid diatoms - a reassessment of their structure and terminology, with particular reference to members of the Cymbellales. Diatom 20: 33-46.

Cox, E.J. (2012) Ontogeny, homology, and terminology - wall morphogenesis as an aid to character recognition and character state definition for pennate diatom systematics. J. Phycol. 48: 1-31.

http://dx.doi.org/10.1111/j.1529-8817.2011.01081.x

Ehrenberg, C.G. (1837) Über ein aus fossilen Infusorien bestehendes, 1832 zu Brod verbacknes Bergmehl von der Grenzen Lapplands in Schweden Bericht über die zur Bekanntmachung geeigneten. Verhandlungen der Königlich-Preussischen Akademie der Wissenschaften zu Berlin 1837: 43-45.

Gelman, A. \& Rubin, D.B. (1992) Inference from iterative simulation using multiple sequences. Statistical Science 7: 457-511.

Guillard, R.R.L., Carpenter, E.J. \& Reimann, B.E.F. (1974) Skeletonema menzelii sp. nov., a new diatom from the western Atlantic Ocean. Phycologia 13(2): 131-138.

http://dx.doi.org/10.2216/i0031-8884-13-2-131.1

Guillard, R.R.L. \& Lorenzen C.J. (1972) Yellow-green algae with chlorophyllide c. Journal of Phycology 8: 10-14. http://dx.doi.org/10.1111/j.0022-3646.1972.00010.x

Gusev, E.S. \& Kulikovskiy, M.S. (2013) A new species of the genus Mallomonas (Chrysophyceae: Synurales), Mallomonas kuzminii sp. nov., from lake Frolikha (Russia, Baikal region). Phytotaxa 155(1): 66-70. http://dx.doi.org/10.11646/phytotaxa.155.1.6

Hall, T.A. (1999) BioEdit: a user-friendly biological sequence alignment editor and analysis program for Windows 95/98/NT. Nucleic Acids Symposium Series 41: 95-98.

Katoh, K. \& Toh, H. (2010). Parallelization of the MAFFT multiple sequence alignment program. Bioinformatics 26: $1899-1900$. http://dx.doi.org/10.1093/bioinformatics/btq224

Kermarrec, L., Ector, L., Bouchez, A., Rimet, F., Hoffmann, L. (2011) A preliminary phylogenetic analysis of the Cymbellales based on 18S rDNA gene sequencing. Diatom Research 26(3): 305-315. http://dx.doi.org/10.1080/0269249x.2011.633255

Kociolek, J.P., Kulikovskiy, M. \& Solak, C.N. (2013) The diatom genus Gomphoneis Cleve (Bacillariophyceae) from Lake Baikal, Russia. Phytotaxa 154: 1-37. http://dx.doi.org/10.11646/phytotaxa.154.1.1

Kociolek, J.P. \& Stoermer, E.F. (1998) A preliminary investigation of the phylogenetic relationships of the freshwater, apical pore fieldbearing cymbelloid and gomphonemoid diatoms (Bacillariophyceae). Journal of Phycology 24: 377-385. http://dx.doi.org/10.1111/j.1529-8817.1988.tb04480.x

Kociolek, J.P., Stepanek, J.G., Lowe, R.L., Johansen, J.R. \& Sherwood A.R. (2013) Molecular data show the enigmatic cave-dwelling diatom Diprora (Bacillariophyceae) to be a raphid diatom. European Journal of Phycology 48(4): 474-484. http://dx.doi.org/10.1080/09670262.2013.860239

Kozhov, M.M. (1950) Fresh waters of East Siberia. Irkutskoe oblastnoye izdatelstvo, Irkutsk, 367 pp.

Krammer, K. \& Lange-Bertalot, H. (1986) Bacillariophyceae 1. Teil: Naviculaceae. Süswasserflora von Mitteleuropa: 1-876.

Krammer, K. (1982) Valve morphology in the genus Cymbella C.A. Agardh. Micromorphology of Diatom Valves XI: 1-299.

Krammer, K. (1999) Validierung von Cymbopleura nov. gen. Iconographia Diatomologica 6: 292.

Krammer, K. (2003) Cymbopleura, Delicata, Navicymbula, Gomphocymbellopsis, Afrocymbella. Diatoms of Europe 4: 1-530.

Kulikovskiy, M.S. \& Kociolek, J.P. (2014) The diatom genus Gomphonema Ehrenberg in Lake Baikal. I. Morphology and taxonomic history of two endemic species. Nova Hedwigia. Beiheft 143: 507-518. http://dx.doi.org/10.1127/1438-9134/2014/027

Kulikovskiy, M.S., Lange-Bertalot, H., Khursevich, G.K. \& Kuznetsova, I.V. (2012c) New diatom species of the genus Eolimna (Bacillariophyceae) from Lake Baikal. News of the taxonomy of lower plants 46: 46-51.

Kulikovskiy, M.S., Lange-Bertalot, H., Metzeltin, D. \& Witkowski, A. (2012a) Lake Baikal: hotspot of endemic diatoms I. Iconographia Diatomologica, V. 23, A.R.G. Gantner Verlag K.G., pp. 7-608.

Kulikovskiy, M., Lange-Bertalot, H. \& Witkowski, A. (2013) Gliwiczia gen. nov., a new achananthoid diatom genus with description of four species new for science. Phytotaxa 109(1): 1-16. http://dx.doi.org/10.11646/phytotaxa.109.1.1

Kulikovskiy, M.S., Lange-Bertalot, H., Witkowski, A. \& Khursevich, G.K. (2011) Achnanthidium sibiricum (Bacillariophyta), a new species from bottom sediments in Lake Baikal. Algological Studies 136/137: 77-87. http://dx.doi.org/10.1127/1864-1318/2011/0136-0077

Kulikovskiy, M.S., Witkowski, A. \& Khursevich, G.K. (2012b) Encyonema horstii sp. nov., a species of unusual valve outline from 
Pleistocene deposits of Lake Baikal. Nova Hedwigia 141: 365-374.

Kützing, F.T. (1844) Die kieselschaligen Bacillarien oder Diatomeen. Nordhausen, 152 pp.

Kuzmina, A.E., Ignatova, N.V. \& Mizandronzev, I.B. (2004) Species composition, ecological and geographical characteristics of the diatoms from Lake Frolikha. Proceedings of the international symposium "Living cells of the diatoms" (Irkutsk) 1: 55.

Lange-Bertalot, H. (2001) Navicula sensu stricto. 10 genera separated from Navicula sensu lato, Frustulia. Diatom of Europe 2: 1-526.

Lange-Bertalot, H. \& Metzeltin, D. (1996) Indicators of oligotrophy - 800 taxa representative of three ecologically distinct lake types, Carbonate buffered - Oligodystrophic - Weakly buffered soft water. Iconographia Diatomologica 2: 1-390.

Mann, D.G. (1981) Sieves and flaps: siliceous minutiae in the pores of raphid diatoms. Proceedings of the 6 ${ }^{\text {th }}$ Diatom Symposium: 279 300 .

Medlin, L.K. \& Kaczmarska, I. (2004) Evolution of the diatoms: V. morphological and cytological support for the major clades and a taxonomic revision. Phycologia 43: 245-270. http://dx.doi.org/10.2216/i0031-8884-43-3-245.1

Mereschkowsky, C. (1903) Über Placoneis, ein neues Diatomeen-Genus. Beihefte zum Botanischen Centralblatt 15: 1-30.

Novais, M.H., Wetzel, C.E., Van de Vijver, B., Morais, M.M., Hoffmann, L. \& Ector L. (2013) New species and combinations in the genus Geissleria (Bacilllariophyceae). Cryptogamie, Algologie 34(2): 117-148.

http://dx.doi.org/10.7872/crya.v34.iss2.2013.117

Posada, D. (2006) ModelTest Server: a web-based tool for the statistical selection of models of nucleotide substitution online, Nucleic Acids Research 34: W700-W703

http://dx.doi.org/10.1093/nar/gk1042

Rimet, F., Kermarrec, L., Bouchez, A., Hoffmann, L., Ector, L. \& Medlin L.K. (2011) Molecular phylogeny of the family Bacillariaceae based on 18S rDNA sequences: focus on freshwater Nitzschia of the section Lanceolatae. Diatom Reserch 26(3): 273-291. http://dx.doi.org/10.1080/0269249x.2011.597988

Ronquist, F. \& Huelsenbeck, J.P. (2003) MrBayes 3: Bayesian phylogenetic inference under mixed models. Bioinformatics 19: 15721574.

http://dx.doi.org/10.1093/bioinformatics/btg180

Round, F.E., Crawford, R.M. \& Mann, D.G. (1990) The Diatoms. Biology \& Morphology of the Genera. Cambridge University Press, Cambridge, 747 pp.

Schmidt, A. (1874-1959) Atlas der Diatomaceen-kunde. Parts 1-120, Pls. 1-460. R. Reisland, Leipzig.

Skabitschevsky, A.P. (1953) Phytoplankton and diatoms of Lake Frolikha (Transbaikalia). Proceedings of the Irkutsk State University. Biological Series 1: 145-152.

Sorhannus, U. (2004). Diatom phylogenetics inferred based on direct optimization of nuclear-encoded SSU rRNA sequences. Cladistics 20: $487-497$. http://dx.doi.org/10.1111/j.1096-0031.2004.00034.x

Stepanek, J.G. \& Kociolek, J.P. (2014) Molecular phylogeny of Amphora sensu lato (Bacillariophyta): An investigation into the monophyly and classification of the amphoroid diatoms. Protist 165: 177-195.

http://dx.doi.org/10.1016/j.protis.2014.02.002

Tamura, K., Peterson, D., Peterson, N., Stecher, G., Nei, M. \& Kumar, S. (2011) MEGA5: Molecular Evolutionary Genetics Analysis using Maximum Likelihood, Evolutionary Distance, and Maximum Parsimony Methods. Molecular Biology \& Evolution 28: 27312739.

http://dx.doi.org/10.1093/molbev/msr121

Timoshkin, O.A. (1999) Biology of Lake Baikal: "White spots" and progress in research. Berliner Geowissenschaftliche Abhandlungen Reihe E Palaeobiologie 30: 333-348.

Zgrundo, A., Lemke, P., Pniewski, F., Cox, E.J. \& Latala A. (2013) Morphological and molecular phylogenetic studies on Fistulifera saprophila. Diatom Research 28(4): 431-443.

http://dx.doi.org/10.1080/0269249x.2013.833136

Zimmermann, J., Jahn, R. \& Gemeinholzer, B. (2011) Barcoding diatoms: evaluation of the V4 subregion on the 18S rRNA gene, including new primers and protocols. Organisms Diversity \& Evolution 11: 173-192.

http://dx.doi.org/10.1007/s13127-011-0050-6 